\title{
Adaptation of transport system in the poultry industry
}

\author{
Jaime Rodriguez ${ }^{1}$, Gonzalo Moreno Contreras ${ }^{1 *}$, and Rafael Bolivar León ${ }^{1}$ \\ ${ }^{l}$ Faculty of Engineering and Architecture, GIMUP group, University of Pamplona, Colombia. \\ *Corresponding Author (gmoren@ hotmail.com)
}

Received Date: December 30, 2021 Accepted Date : January 27, 2022 Published Date : February 07, 2022

\begin{abstract}
In many parts of the world, product transport systems must adapt and provide a solution to the conditions imposed in certain situations, in this sense, in this article a case study is presented in which an adaptation solution is given to a transport system. transport of food in a Poultry Industry in Colombia, in this case the conditions of the land communication routes of the company with its environment are not the best, which causes innumerable problems in the production of the company, therefore an adaptation was made to a transport car anchored to a tractor, which effectively facilitates the transportation of food and products inside and outside the company's facilities, which has implemented this system in all its plants.
\end{abstract}

Key words: Transport systems, suitability, products.

\section{INTRODUCTION}

Within the organizational structure of a company dedicated to the commercialization of products, it is vitally important to have adequate transport systems for its raw materials and products, transport systems fulfill the function of delivering goods at a scheduled time, since the production and preservation of certain products often depend on it, which is why failures and delays in this link in the chain must be prevented, for which a correct selection and implementation of the different transport systems must be made. . In the specific case of land transport, it is important to know the status of the routes, their variants and changes in ground conditions depending on each time of the year, while preventing losses,

For the vast majority of companies, part of their success depends on the effectiveness of their transportation system, both of the raw materials that they need for their production, and of the products that they need to send to their clients. This is the case of a poultry company in Colombia, in said company the access route to its production plant is quite complicated in the rainy season, which often delays and therefore modifies delivery times, poultry feed, which affects the company's egg production, which is its flagship product. As a solution to this problem and taking into account the conditions of the road, the adaptation of a sugarcane wagon was carried out, which is anchored to a tractor for transport in winter seasons.

Within the adaptations of the system, the design of a hopper with an endless screw system was carried out, a practical assembly for the transport and unloading of food, this hopper was adapted on a vehicle with a wagon-type structure in charge of sustaining the design. , this set (hopper and wagon) will be towed by a tractor, which allows the transport of food to be carried out safely in any terrain condition.

This system shows a practical solution that serves as a reference to prevent problems related to inconveniences in the product supply system in areas of difficult access and thus be able to continue with the processes normally, complying with the expected production levels.

\section{CASE STUDY}

As mentioned above, the climatic conditions at certain times of the year make the access routes to the company difficult, as indicated in Figures 1 and 2.

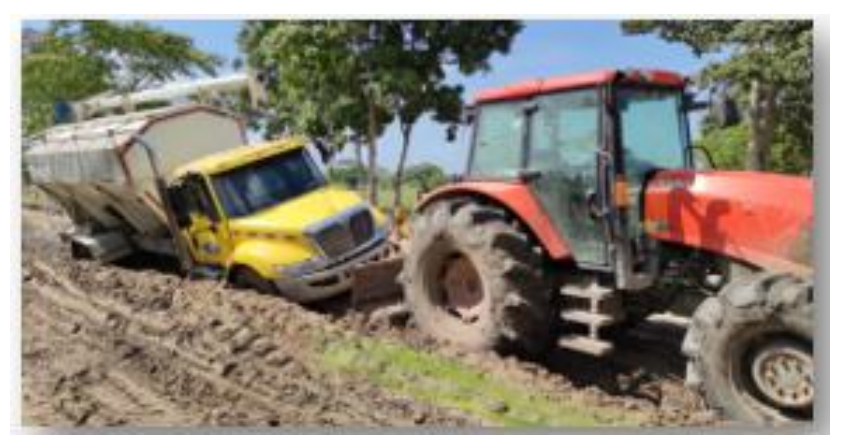

Figure 1: Conditions of access to the company. 


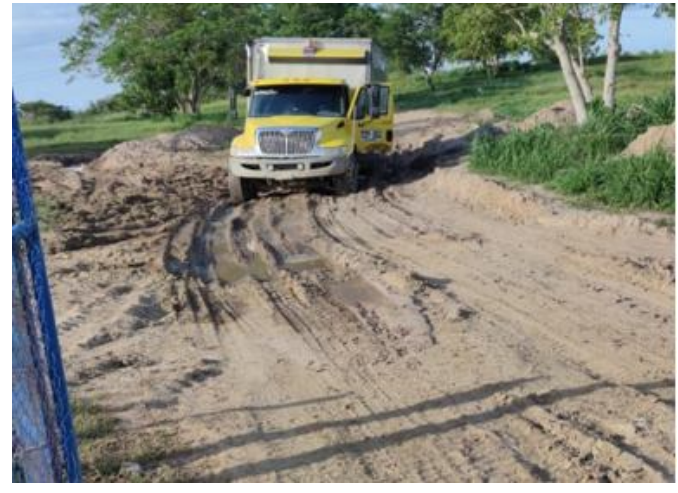

Figure 2: Conditions of access to the company.

Although the characteristics of the vehicles used today are ideal for this type of journey, the roads become impassable, interrupting the collection and distribution, this affects the production process, since it generates additional costs by having to look for a solution to give continuity to the food supply process, many times you have to wait a long time until the roads improve

This fact means that the company's production is restricted at certain times of the year, when the rains are quite frequent, which means that on many occasions the trucks have to wait for a long time for the road to improve or for the Products must be unloaded on the roads and carried by pack animals to the company warehouses, which causes multiple inconveniences, as indicated in Figure 3.

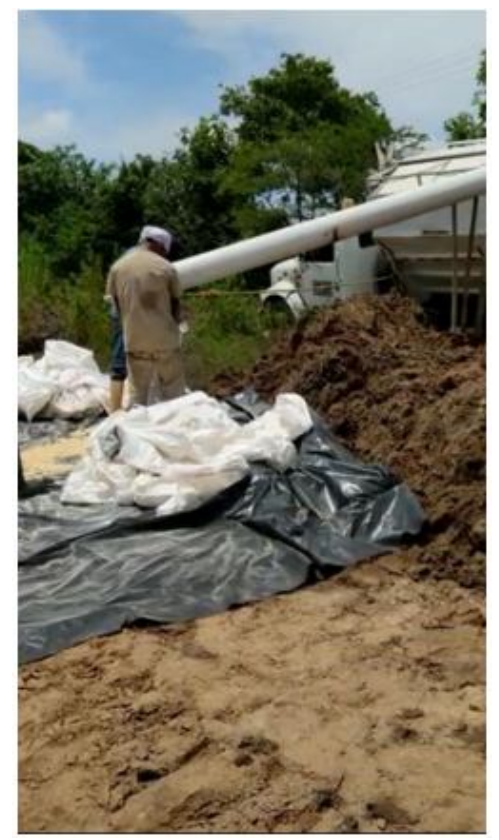

Figure 3: Unloading of food on the company's roads

Taking this situation into account, and observing the experience of other companies in the region in the solution of transport systems $[1,2]$, the company looked for several alternatives, being the most suitable for transport capacity and adaptation to the terrain, the purchase and adaptation of certain vehicles used in the transportation of sugar cane, which are anchored to a tractor and move easily in areas of difficult access, the selected vehicle is shown in Figure 4.

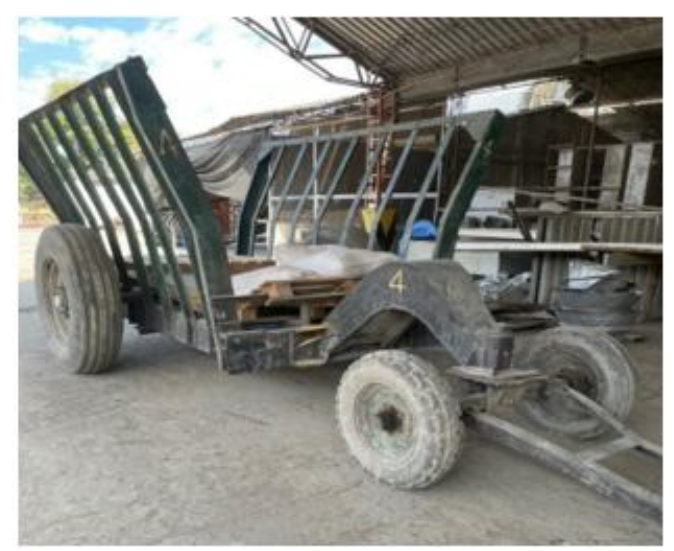

Figure 4: Sugarcane wagon

Once this vehicle was selected, which allows the transport of a large amount of food for the birds (an important condition in the selection), a storage hopper for the product to be transported was developed using a CAD program (Figure 5). this hopper or container was designed taking into account the dimensions and space given by the selected vehicle, additionally, an endless system was designed for this hopper to facilitate the evacuation of the transported products $[3,4]$.

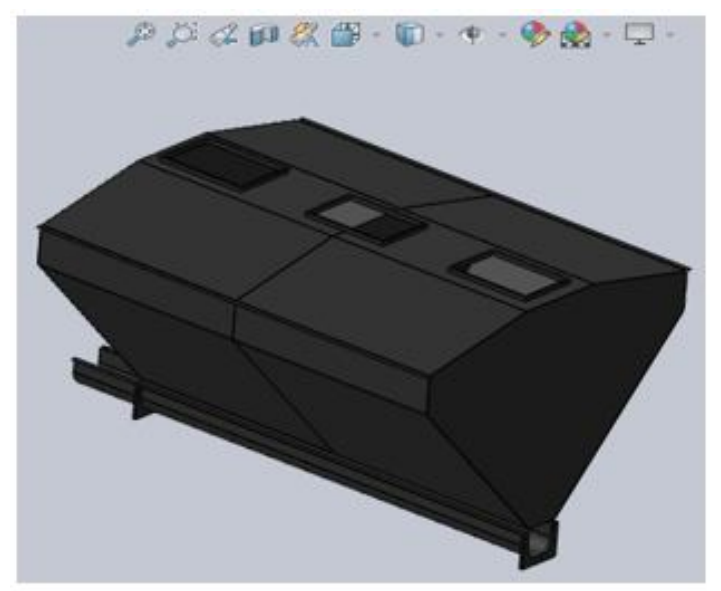

Figure 5: Hopper CAD Design

Once the CAD of the storage system was developed, the respective calculations were made to guarantee the correct functioning of the equipment to be built, therefore the type of products to be transported and the capacity of the hopper were taken into account, which allowed to make a resistant hopper structure, a correct selection of materials, and the design of the endless system at the bottom of the system [3-5]. 
During the construction phase, other changes and adaptations to the system were implemented, in such a way that its operation would be the best and most suitable for the company. Figures 6 - 9 show part of the construction of the transportation system.

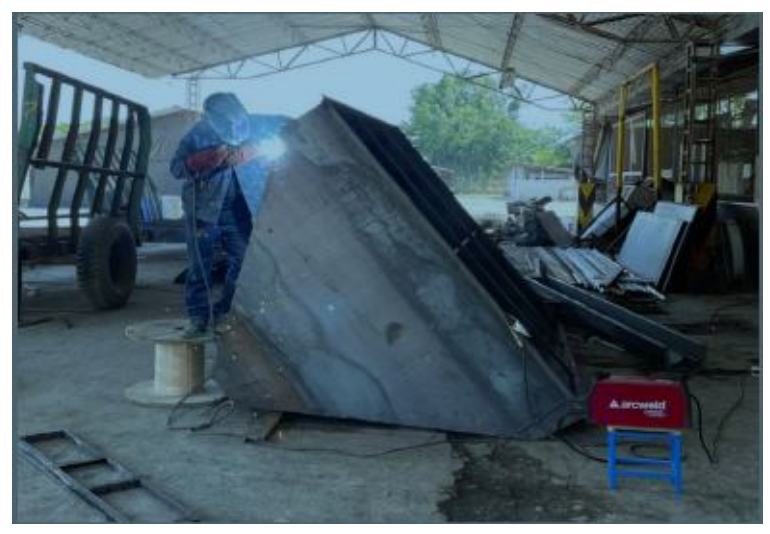

Figure 6: Hopper Construction
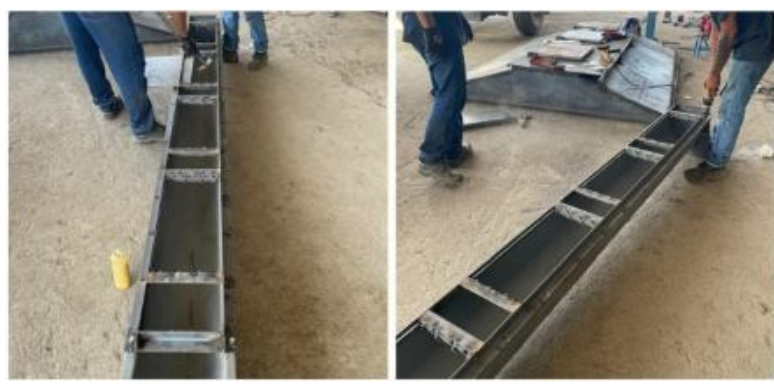

Figure 7: Construction of the endless system

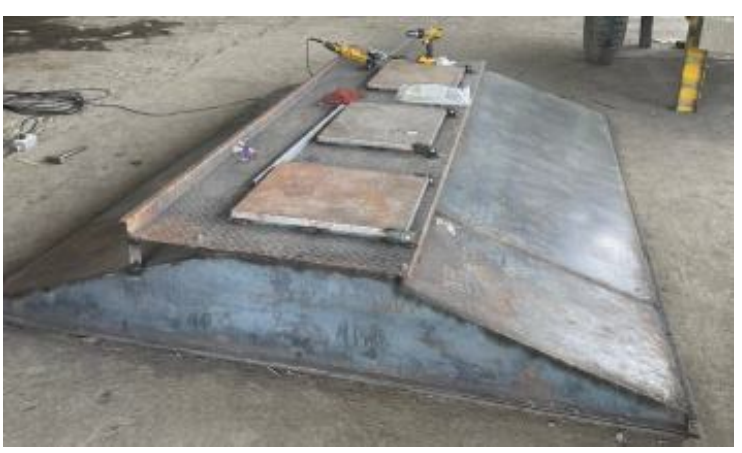

Figure 8: Cap and System Fill System

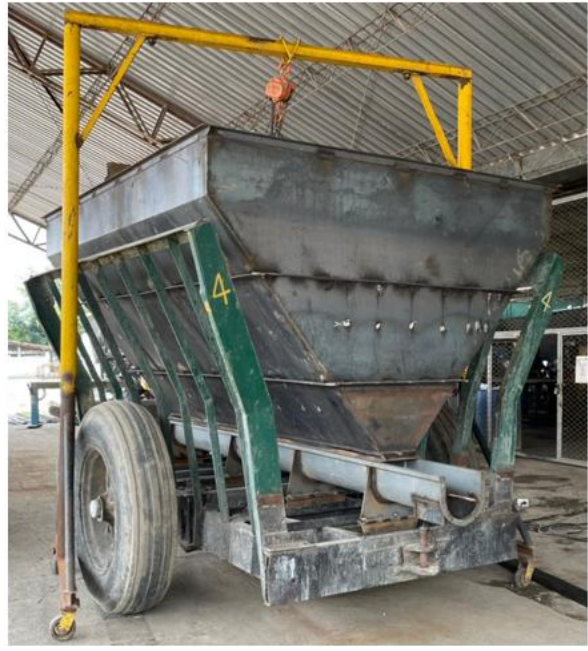

Figure 9: Transport System Assembly

In Figures 7 and 8, it can be seen that gates were fitted to the system to allow the dosage of the product in the endless system, and gates in the lid, in such a way that the distribution of the product in the hopper is homogeneous.

Subsequently, the respective equipment operation tests were carried out, for which an operation and maintenance manual was developed. The system was then delivered to the company and tested under the difficult conditions of the company's roads, as indicated in Figures 10 and 11.

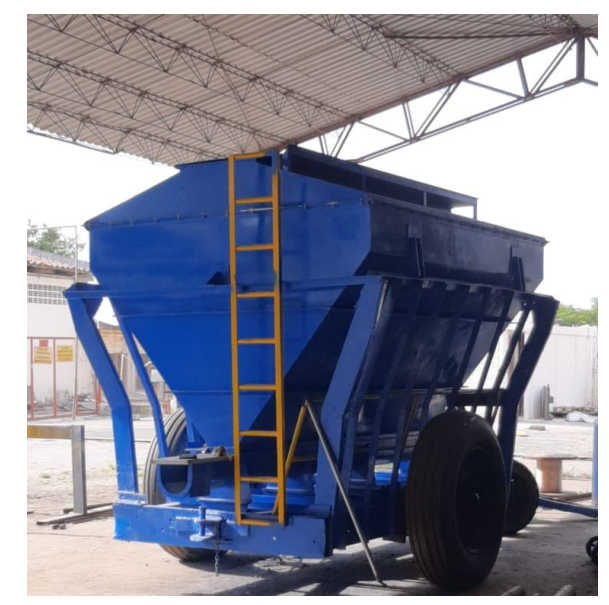

Figure 10: Finished poultry feed transport system 


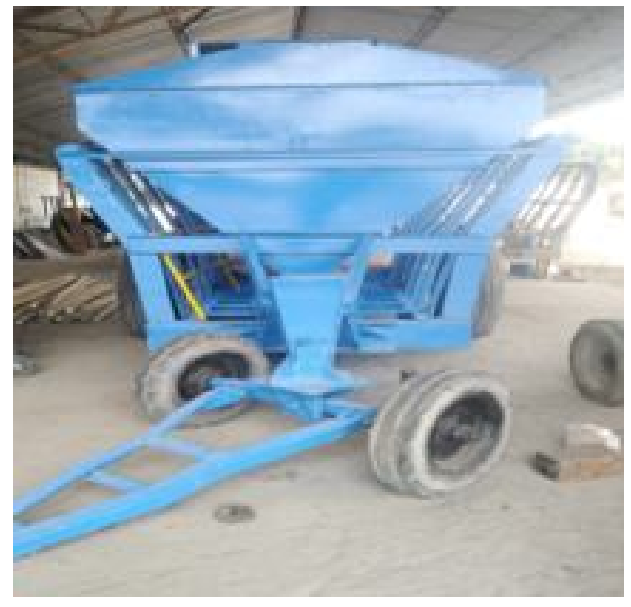

Figure 11: Finished poultry feed transport system

\section{CONCLUSIONS}

As indicated by the company, the equipment designed has allowed the transport times of the food for the birds to be adequate, which has allowed their feeding to be done at the times indicated in their production process, as a result the company does not affect or delay its production process and comply with production times and with its customers.

Due to the good results of the designed system, the company has replicated this system in several of its plants nationwide.

\section{REFERENCES}

1. JAIMES VOLLMUTH, Zully Tatiana, et al. Propuesta de transporte costo efectiva de maíz amarillo a la planta de Avidesa Mac Pollo SA, tramo Barranquilla-Girón. Colombia

2. CÁNOVAS, Alfonso Cabrera. Transporte internacional de mercancías. ICEX España Exportación e Inversiones, 2011.

3. LIMO HUAMÁN, Rafael Enrique. Implementación de un sistema de control semiautomático en silos y tolvas de almacenamiento para mejora de la productividad en el procesamiento de alimento balanceado en una planta del sector avícola. 2017.

4. MOYA BEJARANO, Cristian Patricio. Diseño de un dosificador semiautomático por tornillo sin fin para Uchu Jacu en la Organización Unopac de la Parroquia Ayora del Cantón Cayambe. 2016. Tesis de Licenciatura.

5. BUDYNAS, Richard Gordon, et al. Shigley's mechanical engineering design. New York: McGraw-Hill, 2011 